\title{
Hatalı Perspektifler
}

\section{E. D. HIRSCH}

\author{
ÇEV. DR. MUAZZEZ USLU**
}

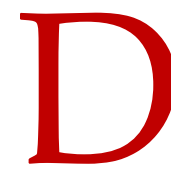

ogmatik şüphecilik(septisizm) için bugün edebiyat kuramindaki temel entelektüel (ve duygusal) hizip bütün bilginin göreceli olduğu varsayımıdır. Benim deyimimle bu bilişsel ateizm temelde herkesin edebiyatı kendi "bakış açısından" gördüğü ve kendi değer ve ilişkilendirme sistemleriyle edebiyata duygusal tepkiler verdiği düşüncesi üzerine kuruludur. Bu şekilde bireyselleştirilirse, bilişsel ateizm düpedüz öznelciliktir. Fakat bilişsel ateizmle yakından ilişkili diğer kavramlar, kültürel görelilik (rölativizm), tarihsel görelilik ve metodolojik göreliliktir. Hepsi aynı yapıyı sergiler, hepsi hakikat ve gerçeği ruhsal perspektife bağlı tutar. Eleştirel görecelik doktrinini, eleştirel şüphecilikten ayrılan, kendi yandaşlarına yıkıcı bir tutarsızlıkla hatta tuhaf bir paradoksla saldıran tek doktrin olmasıdır. Sabit fikirli bilişsel ateizm geliştirilmiş bir sistemden çok duygusal olarak verili bir sistem olma eğilimindedir. Ancak sadece tutarsızlık, edebiyat kuraminda dogmatik şüpheciliğe engel değilse, yine de bilişsel göreceliğin deneysel olarak yanlış öncüller üzerine kurulu olduğu gösterilirse bilinemezciliğe (agnostisizme) bir geçiş beklenebilir.

\section{PERSPEKTIFF MECAZI}

Bir nesnenin uzayda farklı noktalardan bakıldığında değişen görünümlerini ilgilendiren sözcükler modern Avrupa dillerinde kelime dağarcıklarına oldukça geç girmiştir. Perspektif sözcükleri antik Yunan ve Roma kelime dağarcıklarında hiç bulunmaz. Doğu bu konuda belli ki vaktinden evvel olgunlaşmıştır. Erken dönem Çin ressamlarının gerçek uygulamalarından elde edilen kanıtlar, uzayda bir noktadan tek gözle bakıldığında bozuk bir görüntü elde edileceğini sistematik bir biçimde anladıklarını gösterir. Fakat Batı'da uzaysal olarak bir noktaya konumlanmış bir görüşün sistemik bir biçimde bozulması anlamına gelen "perspektif kuralları" 15. yüzyıla kadar anlaşılamamıştır. 15. Yüzyıl, ressamların iki boyutlu yüzeyler üzerinde tek gözle bakıldığında elde edilen bir perspektiften temsil ilkelerini çalıştıkları dönemdir.

\footnotetext{
* Hirsch Jr., E. D. (1988). "Faulty Perspectives", Modern Criticism and Theory (Modern Eleştiri ve Kuram). David Lodge ve Nigel Wood (Yay. Haz.) (s. 253-263). London and Newyork: Longman (Birinci Baskı).- Bu çeviri belirtilen kaynak eserden yapılmıştır. Ancak makale ilk olarak Essays in Criticism(Vol. XXV No. 1) adlı edebiyat dergisinde 1975 yılında yayınlanmıştır. İkinci olarak, yazarın The Aims of Interpretation (1976) adlı yazarın makalelerini bir araya getirdiği seçkide yer almıştır.

*** Muğla Sıtkı Koçman Ün. İngilizce Mütercim Tercümanlık Böl. muslu@mu.edu.tr, orcid.org/0000-0001-6546-738X. 
Batılı ressamlar için kendi illüzyonist sanatlarının temel prensiplerini keşfetmek neden bu kadar uzun sürmüştür? Bu sorunun cevabı belki de gelişim psikolojisinde, özellikle Piaget'nin küçük çocuklarla yaptı̆̆ deneylerde bulunabilir. Her çocuk, dünyayı görsel olarak yorumlamayı öğrenirken, perspektif etkilerini telafi etmek için uzun, meşakkatli, hatalarla dolu bir süreçten geçmek zorundadır. Bu

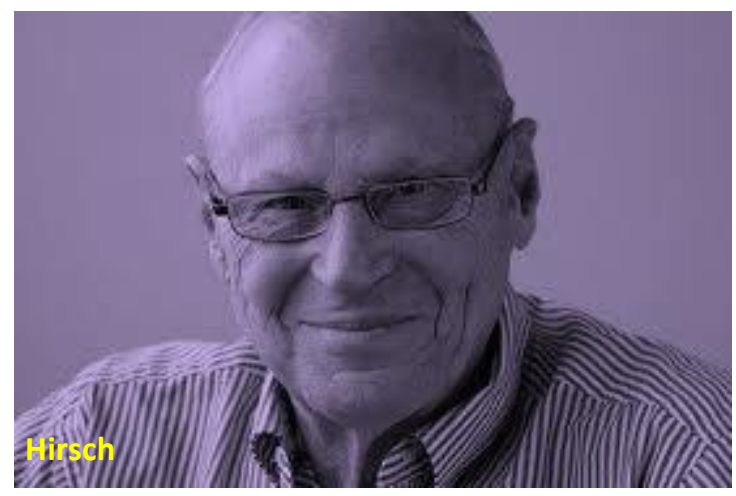
süreçten geçerken, normal bir çocuk tabii ki doğuştan sahip olduğu dâhili bir perspektif dengeleyicisinin, yani her iki gözünde kullanımını gerektiren bir bakış açısının büyük ölçüde desteğini alır. Çocuk başlangıçtan itibaren çift perspektife sahiptir; dünyaya hep iki bakış açısından bakar. Bu iki nokta arasındaki mesafe sürekli var olduğundan, bir gözle elde edilen dünya manzarasının bozukluklarını yeniden yorumlamayı yavaş yavaş öğrenir. Bu yüzden perspektif kuralları bu kadar zor, gayri tabiidir ve bu kadar geç keşfedilir. Perspektif kurallarını öğrenmek, Piaget'nin belgelediği gibi çocuklukta öğrenilen temel ve zahmetli perspektif derslerini aklından çıkarmayı gerektirir. Bu yapı bozum süreci o kadar asicedir ki ilk araştırmacılar, Dürer'in "Persfektifin Gösterimi" adlı çalışmasında tasvir ettiği camera obscura (karanlık oda)1 gibi cihazlara gereksinim duymuşlardır.

Batı kültürünün perspektif etkilerini, bakış açısı (1856), duruş noktası (1836), zihinsel perspektif (1841) ve duruş (1837) gibi mecazlarda temsil edildiği gibi, tinsel teşbihlerde keşfetmesi daha uzun zaman almıştır (Parantez içindeki tarihler bu tür mecazi kullanımların Yeni İngilizce Sözlük'te (New English Dictionary) kaydedilen ilk kullanım tarihlerini göstermektedir). Rönesans ressamlarının karanlık odaya gereksinim duyması gibi, Victoria döneminde yaşayanlar da bu tür tinsel benzeşimleri kurabilmek için Kant’a gereksinim duydu. Tek gözle bakışın bozuk bir görüntüye neden olmasına benzer bir şekilde, bir kişinin gerçeklik algısının kendi tinsel konumu yüzünden bozuk olduğunu varsaymak Kant felsefesinin Kopernikçi devrimini gerektirdi.

Fakat eleştirel felsefenin amacı bilginin geçerliğini ve evrenselliğini savunmak olduğundan, bu benzeşimde ima edilen görecelik en büyük hicivdir. Bu sadece bir hiciv değil, muazzam Kant kavrayışının tamamen bayağılaştırılmasıdır. Bu bölüm bu türden bazı bayağılaştırmaların yorumbilgisel (hermeneutik) kuram alanındaki bir eskizi ve eleştirellikten ve derinlikten uzak uygulamalarına karşı bir tartışmadır.

\section{Tarih Perspektifi: Göreceli Üç Yanlış Kanı}

18. Yüzyılın sonlarında insan doğası perspektifinin bütün yer ve zamanlarda aynı olduğu

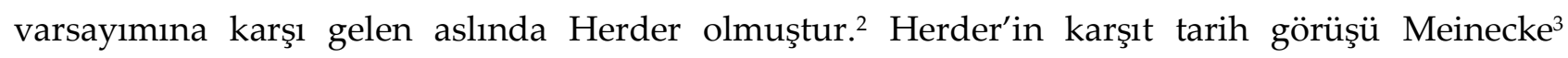
tarafından “tarihselcilik” diye adlandırılmıştır. Meinecke, Herder'in görüşünü “Batı Düşününün

\footnotetext{
${ }^{1}$ Yazarın notu (Y.N.) Metinde "oscura" olarak yazılan kelimenin "obscura" olduğu bir basım yanlışından kaynaklandığı açıktır.

${ }^{2}$ Y.N. Johann Gottfried von Herder (1744-1803), Alman filozofu, şair ve eleştirmen. İnsan Felsefesinin Anahatları (Outlines of the Philosophy of Man) adli eserin yazarı.

${ }^{3}$ Y.N. Friedrich Meinecke (1862-1954), Alman tarihçi.
} 
tecrübe ettiği en büyük devrimlerden biri" olarak değerlendirir. Şüphesiz Meinecke haklıdır. Ve bu devrimin etkilerinden biri tarihsel tasvir alanına perspektif mecazının tanıtılması olmuştur. Tarihçiler insan perspektifinin farklı çağlarda farklı olduğunu varsaymadan önce, Romantik Çağın Tini (Zeitgeist) ya da Orta çağın Aklı üzerine monograflar yazmaya başlamamışlardır. Çeşitli kapsamlılık derecelerinde bu tür perspektife dair fikirler şu an edebi tarihin esaslarıdır.

Meinecke'ye göre tarihselciliğin esas özelliği "insan olguları hakkındaki genelleştirici düşünce biçiminin bireyselleştirici bir düşünce biçimiyle değiştirilmesidir". Ama Meinecke'nin tanımı sadece eleştirel olmayan biçimleriyle modern tarihselcilik ya da kültürel perspektivizm için geçerlidir. Edebi tarih sıklıkla bir dönemin içindeki uyumsuz bireysellikleri vurgulamadan bir dönemin bireyselliğini vurgular. Bu tuhaftır çünkü bir dönemin içindeki bireylerin aynılığını anlayanlar farklı dönemlerdeki bireylerin aynılığını pek anlayamazlar. Meinecke'nin kendisi bu tutarsızlıktan kaçınan ayrıcalıklı tarihçilerden birisidir. $\mathrm{O}$, insan perspektifinin tarih içerisinde radikal bir şekilde değiştiği varsayılırsa, edebi tarihi de kapsayan herhangi bir tür tarihin mümkün olamayacağını ve insan doğasının her yerde aynı kaldığı varsayılırsa da bunun boş bir varsayım olacağını söyler. Her iki şekilde de eleştiriden uzak olan bu dogma bir yanılgı olarak adlandırılmayı hak eder. Ve tabii ki bu mantıksal bir yanılgı değil, deneyime ve sağduyuya karşı bir suç olacaktır.

Listemdeki üç tarihselci yanılgıdan ilki, nüfuz edilemez [anlaşılamayacak kadar esrarl14] bir geçmiş yanılgısıdır; çünkü bu öğenin altında geçmişteki kişilere, romanlarda İngilizlerin Doğululara baktıkları şekilde esrarlı bir gözle bakılır. Bu tarz edebiyat tarihçileri, bizimkinden o kadar farklı bir ruh haliyle tarihten anlam çıkarırlar ki, metinler sadece özel olarak yetiştirilmiş az sayıda kişi tarafından anlaşılabilir ve onların da Marstan gelmiş olabilecek insanlarla dolu bu uzak çağ1 anlayabilmek için "tarihsel empati” eylemine gereksinimleri vardır. Bunu göstermek için Profesör Bruno Snell'in çıkarımlarını alacağım. İlyada ve Odise'nin etkileyici bir sözcüksel (lexical) incelemesini yaptıktan sonra, Profesör Snell, Homeros'un günlerindeki Yunanlıların bilinçli bir öz benlik algısına sahip olmadıkları sonucuna varır; Homeros'un şiirlerinde böyle bir düşünceye dair herhangi bir kelime yoktur. Aynı sözcüksel çıkarım süreciyle, Yunanlıların tek bir insan vücudu algısına da sahip olmadıklarını bulur. Homeros'un şiirleri sadece insan vücudunun parçalarına atıfta bulunur, hiçbir zaman bütününe değil. Öyleyse Yunanlılar, alışılageldiği üzere, insan vücudunu sadece bir parçalar kümesi olarak algılamış olmalılar. Profesör Snell'in haklı olabileceği ihtimalini yadsımıyorum, ama haklı olma ihtimali aşırı derecede olanaksızdır. Tarihin nüfuz edilemez olduğu yönündeki hatalı bir fikri onurlandıran bir geleneğin içinde öğrenim görmemiş olmasaydı, bu kuramları geliştireceğinden şüphe duyuyorum.

${ }^{4}$ Ç.N. (Çevirmenin Notu): Köşeli parantezler çevirmenin açıklayıcı notlarını içermektedir. 


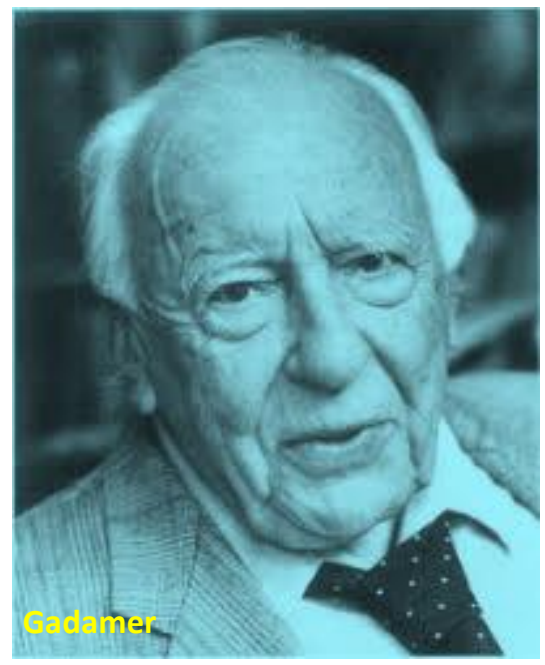

Snell'in kitabı etkili olmuştur, fakat bu kitabın ilginç ve ihtimal dışı fikirlerini ve edebiyatçılar tarafından yazılmış bunlara benzerlerini, bugünün kuramcıları arasında yıkıcı bir tepki yaratmamış olsalardı suçlayamazdık. Mesela Gadamer ${ }^{5}$ gibi, Barthes gibi kuramcılar geçmişin "yeniden yapılandırmaları" üzerine kurulmuş bu tür kültürel nekrozlara haklı olarak karşı koyarlar. Buna panzehir olarak da geçmişin esrarlı metinlerini kendi perspektifimize göre bozarak canlandırmamızı önerirler. Bir başka deyişle, geçmişi çözülemez bir esrar olarak görme hatasını, üzerine kendi şüpheci karşı önerilerini kurdukları bir öncül olarak kabul ederler. Tarihi ilginç ve geçerli bir biçimde bozmak, tarihsel yeniden yapılandırma adı altında bozup öldürmekten çok daha iyidir. Bu durumda hem tarihsel yeniden yapilandirmasıla Snell, hem de tarihsel canlandirmasiyla Gadamer uç noktada tarihselci ve perspektifçidir. Farklı görünseler de kardeştirler. Her ikisi de geçmişin perspektifle yönetilen anlamlarının bize yabancı olduğunu varsayar. Bir durumda [Snell'in önerdiği gibi] kendimizinkine benzemeyen bir gerçeğe ve insani durumu kabullenecek bir perspektife girmemiz istenir. [Gadamer'in önerdiği] diğer durumda ise, kendi ilgilerimize uymayan oldukça yabancı bir gerçekliği görmezden gelmemiz ve bunun yerine kendi perspektifimizden kullanılabilir bir geçmiş inşa etmemiz önerilir. Eğer bu noktada gerçekten Snell ve Gadamer arasında bir seçim yapmamız gerekirse, etik tercih Gadamer'den yana olacaktır; çünkü tarihi işe yarar bir biçimde bozmak işe yaramaz bir biçimde bozmaktan daha iyidir. Fakat hatalı fikirlere dayanan bir seçim yapmamız gerekmez.

Tarihselciliğin ele alacağım ikinci yanılgısı, homojen geçmiş yanılgısıdır. Görünen o ki bu yanılgı, Homeros'un günlerindeki Yunanlıların, tek bir öz benlik fikrinden yoksun olduklarını söyleyen Snell'in durumunda olduğu gibi, nüfuz edilemez bir geçmiş yanılgısına eşlik eder. Bu yanılgının altında, Elizabeth dönemi, Romantik dönem ya da Perikles dönemlerinden birinde metin yazmış herkesin, parçası olduğu kültürün kendisine dayattı̆̆ı genel bir perspektifi paylaşması yatmaktadır. Bu öncül üzerine yazan edebiyat tarihçileri aşağıdaki gibi argümanları uygulamaktan memnundurlar.

Orta çă̆ insanı simyaya inanırdı.

Chaucer Orta çağda yaşadı.

Chaucer simyaya inanirdı.

Bu tür yekpare kültürel perspektivizmin en seçkin örneği D.W. Robertson'dır. Robertson'ın uygun bir örnek teşkil ettiği muhakkaktır, çünkü Snell gibi o da bu yanılgıyı çok su katılmamış bir biçimde sergiler. Tabii ki, homojen geçmiş fikrinin hatası, oldukça çürütülemez yapıdaki mantığında değil, Orta çağ'ın düşünce yapısı, Yunan düşünce yapısı ya da Victoria döneminin düşünce yapısına dair ana öncülünün makul olmayışında yatar.

Eleştirel bir biçimde kullanıldıklarında tabii ki Victoria dönemi düşünce yapısı gibi kavramlar tamamen mantıklıdır. Paylaşılan bir kültür aslında kültürün ve perspektifin 
paylaşıldığı yerlerde paylaşılan bir tinsel perspektif demektir. Hatta orta çağa dair tuhaf görünümlü genellemeler araç olarak, yani farklı bir kültürel çevreye giden yolu açan yöntemsel araçlar olarak, kaldıkları sürece faydalıdır. Fakat edebiyat tarihinin uygulandığı kadar soyut bir boyutta olsa bile, herhangi bir kültürel çevrenin homojen olduğunu varsaymak, çelişkili deneyimleri olan insan toplulukları hakkında sadece bir varsayımda bulunmaktır.

Son olarak üçüncü tarihsel yanılgı, öncelikle ortaya çıkarmak istediğim yanılgı, homojen bugün perspektifidir. Örneğin Gadamer sadece bu ek yanılgıyı kabul ederek Snell'e bir alternatif sunabilir. Gadamer yapmacık tarihsel yeniden yapılandırmanın “ölülüğüne” saldırdığında, bugünün de sıra dışı bir biçimde ölü olduğunu varsayar. Fakat tarihsel yeniden yapılandırma kime göre ölüdür? Homojen bir "biz"e karşı mı? Jan Kott ${ }^{6}$ bizi kendi çağdaşlarımız Shakespeare ile tanışmaya davet eder, Roland Barthes bizi çağdaşımız Racine ile tanışmaya ve onu bizimle konuşturmaya davet eder. Fakat bugün perspektifimizdeki bu homojenlik, küçümsediğimiz geçmişe dair yeniden yapılandırmalar kadar yapay bir kurgudur. Bu Herder'in insanlığın hem geçmiş hem de gelecek çoğulculuğuna dair samimi fikirlerine tamamen aykırıdır.

Daha sonra buna benzer kuramlarda, demek ki Herder'in insanın ve kültürlerin bireyselliği fikri bayağılaştırılmıştır. Herder'in çağdaşlarından Vico'nun Herder'in fikrini tamamlayan fikri tanınmamıştır. Erich Auerbach, Vico'nun fikrini şöyle ifade eder: “İnsanlık tarihinin tüm gelişimi insanlar tarafindan yapıldığı için belki de insan zihninde potansiyel olarak vardır, dolayısıyla araştırma ve yeniden çağrışım süreciyle insan tarafından anlaşılabilir". Herder'e göre, insan ve kültür sıklıkla birbirinden oldukça farklıdır demek, bir kişinin kendisinden çok farklı bir perspektife sahip birini anlayabileceğini inkâr etmek değildir. Daha sonra Dilthey tarafindan detaylandırılan Vico'nun düşüncesine göre, insanlar, olduklarından farklı olma potansiyelini paylaşırlar. Bir kültürle başka bir kültür arasındaki mesafe her durumda aşılabilir olmayabilir, ama bu aynı kültürün içinde yaşayan insanlar için de geçerlidir. Benim saldırdığım türden kültürel perspektifçilik, bir kültürel dönemle bir başkası arasındaki mesafenin, herhangi bir yer ve zamanda yaşamış olan başka birini anlamak için atlamamız gereken devasa metafizik aralığa kıyasla çok küçük bir adım olduğunu unutur.

\section{Yaklaşım Nedir?}

Dilthey ${ }^{7}$ ın psikolojik geçmişi anlama modeli ikna edici ve dengelidir. Fakat yazılarında her zaman bu dengeyi korumayı başaramaz. Dünya görüşü ( Weltanschauung)- bir kişinin ve kültürün tinsel perspektifi - tabirini temelde ona borçluyuz. Edebiyat eleştirisi alanında, eleştirmenin dünya görüşüne bazen onun yaklaşımı denir. Bu terim ilk defa 20. yüzyılda perspektifle ilgili bir anlamda kullanılmıştır. Eleştirmenin edebiyat yorumu onun yaklaşımına dayanır. Bilim insanının keşfettiği şey yaklaşımına dayanır. Bu terim metodolojik bir perspektif ima eder.

Dilthey dünya görüşü tabirini kullanmaya başlamadan önce gördüğü bir kâbusun hikâyesini şöyle anlatır. Bir arkadaşının evinde misafirken, Raphael'in Atina Okulu adlı resminin bir reprodüksiyonunun hemen yanına konulmuş bir yatak görür ve uyurken resmin canlandığına dair

\footnotetext{
${ }^{6}$ Y.N. Shakespeare Çă̆gaşımız adlı eserin yazarı Polonyalı göçmen eleştirmen ve tiyatro yapımcısı.
}

${ }^{7}$ Y.N. Wilhelm Dilthey (1833-1911), Alman Filozof ve sosyal bilimci. 
bir rüya görür. Antik devrin tüm filozofları dünya görüşlerine göre gruplara ayrılmaya başlarlar. Rüyadaki bu kompozisyona Kant, Schiller, Carlyle, Guizot gibi daha genç düşünürler de katılır, onların her biri de Platon, Herakles ve Archimedes'in etrafında oluşturulmuş gruplara doğru çekilirler. Gruplar arasında gidip gelen başarısız da olsa aracılık etmeye çalışan başka düşünürler de vardır. Aslında her bir grup sadece kendi arasında iletişim kurabilir hale gelinceye kadar gruplar birbirinden ayrı düşerler. Düşünürler kendi yaklaşımları içerisinde gerçekten izole olurlar. Sonra Dilthey rüyasından uyanır ve rüyayı şöyle yorumlar; her yaklaşım kısmidir ve diğer yaklaşımlarla kıyaslanamaz. Kendi bütünlükleri içerisinde tüm yönleri derinlemesine görmek bizim için imkânsızdır. Fakat uyanırken şu Dilthey için bir teselli olur: her yaklaşım kısmi ve sınırlı olabilir fakat her biri kendine has belli gerçeklik öğelerini ortaya çıkarır.

Edebiyat eleştirisi tarihi ve tüm bilim camiası Dilthey'ın kâbusunun kendilerine has bir türünü üretir. Raphael'in dökümlü kıyafetler içerisindeki vücudunun üstüne farklı yüzler kopyalayıp yapıştırmak yeter. Solda en uç noktada, Freud'un etrafını bir grup sarar, fakat Jung'un etrafını saran hemen yanlarındaki bir başka grupla iletişim kurmayı reddederler. Solda tabii ki başka bir sakallı Alman, Marx, sayısız taraftarıyla ve sağın en ucunda da yine bir başka Alman, Schleiermacher bazıları da MLA $^{8}$ damgalı yaka rozetleri olan bir sürü filolog tarafından sarılır. Merkezde, Platon ve Aristoteles taraftarlarını bir arada tutmayı beceremezler. Winters ve Leavis, Coleridge, Arnold ve Johnson'1 takip ederek bir ileri bir geri gidip gelirler. Başka pek çok şahsiyet de kompozisyona girer. Bir grup tereddüt eder. Başka üstatlara doğru yönelip ayrılırlar. Sonra şaşkınlıkla yeniden gruba katılırlar, hızlı hızlı Fransızca konuşurlar. Bu noktada rüyayı gören kişi huzursuzlanıp uyanır.

Bu kâbus ne anlama gelir? Dithey'ın yas dolu yorumu doğru mudur? Her eleştirel yaklaşım kendini destekleyen perspektifte sonsuza kadar tuzağa düşmüş kısmi bir gerçek mi yansıtır? Ya da daha kötüsü, her yaklaşım kendi perspektifinden görüldüğü kadarıyla bütün (ve bozuk) bir edebiyat biçimi mi yansıtır? Bilgiye ulaşmayı amaçlayan herhangi biri için, bu rüyanın yorumlarından her biri bir kâbustur. Eğer farklı anlamları destekliyorsa eleştirel yaklaşımlar birbirlerini destekleyip tamamlayamazlar. Eğer modelimiz her farklı bakışın bize farklı bir karatavuk [bir kuş türü] görüntüsü verdiğini varsayıyorsa, bir karatavuğa on üç farklı yönden bakıp daha doğru bir karatavuk bulamayız. Sonuç bir karatavuğa on üç farklı karatavuk olacaktır; yani kıyaslandığında, aynı metnin on üç farklı yorumu. Yaklaşım kelimesinin perspektifle ilgili gizli anlamları bizi mantıksal olarak, aynı yöntemleri kullanan bilim insanlarının ve eleştirmenlerin aynı gerçekler hakkında konuşmadıkları ya da algılayamadıkları sonucuna götürür.

Genellikle bu çıkmaz insanın aklına kör adam ve fil hikâyesini getirir ki bu hikâye Dilthey'ın kâbusunun Anglo-Saxon versiyonudur. Kör adam bir filin kuyruğuna dokunduğunda onun bir yılan olduğunu, bacağına dokunduğunda ise ağaç olduğunu

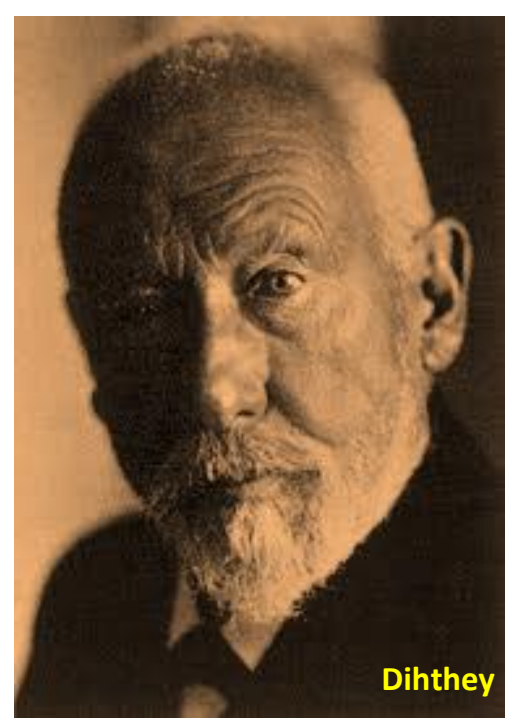

${ }^{8}$ Y.N. Modern Language Association, Modern Dil Birliği. 
düşünür. Fakat bu hikâyenin kendisi edebiyat eleştirisinde yol açacağı anlam çıkarımından çok daha mantıklı ve rahatlatıcıdır. Zeki ve enerjik bir kör adamın ortalıkta dolaşıp yaratığın farklı parçalarına dokunması ve bir file dokunduğu sonucuna varması makuldür. Fakat yaklaşım kelimesi hikâyenin başka bir versiyonuna işaret eder ki bu durumda bu tür bir kararlılık imkânsızdır. Bu hikâyede, pek çok kör adam filin bacaklarından birinin etrafında farklı pozisyonlarda durmakta fakat dokundukları şeyin ne olduğu konusunda fikir ayrılığı yaşamakta ve bu konuda israrcı davranmaktadirlar.

Hikâye şu şekilde anlatılmak zorundadır; çünkü hiçbir eleştirmen, önünde yaklaşılacak bir anlam olmaksızın metinsel anlama herhangi bir yönden yaklaşamaz. Metinsel anlam bir fil ya da bir ağaç gibi farklı bakış açılarından yaklaşılacak bir şey değildir. Eleştirmen onu çözümleyinceye kadar ortaya çıkmaz. Marksist bir eleştirmen bir metni biçimselci bir eleştirmenden farklı bir biçimde çözümlerse, bu konu dışı bir kazadır. Hiçbir perspektif bunu gerektirmez. Marksist ve biçimselci eleştirmenler bir metnin ne anlama geldiğini eşit bir biçimde anlayabilirler. Genellikle ayrıldıkları nokta bu anlama verdikleri önemdir.

Bir eleştirmenin yaklaşımı ne olursa olsun, muhakkak onun anladığı şeyi takip etmelidir. Bir yaklaşım yazılı sembollerin anlamı çözümlendikten sonra gelmelidir. Anlam çözümlemesi farklı eleştirel yaklaşımlarla değişen bir şey değildir. Farklı konumlardan bakıldığında farklı görünümler sergileyen fiziksel bir nesne de değildir. Anlam tek, ayrıcalıklı ve eleştiri öncesi bir yaklaşımdan dolayı var olan bir nesnedir. Eleştirmenler eleştirel yaklaşımlarında ne kadar farklı olurlarsa olsunlar, eğer bir metni anlamaları gerekiyorsa eleştiri öncesi bir yaklaşımla anlamalıdırlar.

\section{Perspektifçiliğin Paradoksları}

Perspektifçiliğin (yorumun, yorumlayan kişinin bakış açısına göre değiştiği kuramının), eleştirel şüpheciliğin bir kök formu olduğunu savundum. Perspektifçilik dolaylı olarak yorumu yapan kişinin değer yargılarından ve peşin hükümlerinden bağımsız bir yorumun imkânını reddeder. Nihayetinde ulaşılabilir bir amaç olarak yorumun doğruluğunu reddeder. Tüm yorumlar perspektife bağlı olarak şekillendiğinden, tamamen farklı yorumlar ayn derecede doğru ya da aynı derecede yanlış da olabilir ki o da aynı anlama gelir. Fakat bu durumda kabul edilebilir bir eleştirel standart olarak ne kalır? Özgünlük mü? Geçerli bir yorumlama, kişinin kendi perspektifi ya da kendi zaman ve kültüründe anlamın özgün bir kavrayışını temsil eder. Perspektifçiliğin gerçekçi amacı, pozitif ölçütler içerisinde, doğruluğun anlamsız ölçütünün, özgünlüğün tahminen anlamlı ölçütüyle değiştirilmesi girişimi olarak ifade edilebilir.

Muhafazakâr bilim insanları, Roland Barthes'ın perspektifçi Racine yorumlamalarına saldırdıklarında, konunun neden tamamen çözülebilir olmadığını ancak şu açıklar: tartışmanın koşulları oransızdı. Bir yorumun orijinalliği sadece "yanlış" olduğu için azalmaz. İşte bu aynı uzlaştırılamaz standartlar çatışması, İncil çalışmalarında Karl Barth gibi “doğrucu” yorumcular ve Rudolph Bultmann gibi "özgüncü" yorumcular arasında geçen benzer kalem kavgalarını çözümlenemez duruma getirmiştir. Belli ki, somut yorumlar hakkındaki tartışmalar, temel ölçüt çatışmaları çözülmeden halledilemez. Perspektifçiler için, geçerlilik tamamen bir metnin ve bir kişinin kaçamayacağı kültürel kimliğinin çarpışması işlevidir. 
Fakat bütün bunlardan sonra perspektif nedir? Bu mecaz uzaysal ve görseldir, öbür taraftan ele aldığım konu [yorumlama] ne uzaysaldır ne de görsel. Bu mecazı geçici bir süre için daha betimleyici yöntemler lehinde terk etmek gerekirse, bu görsel mecazın felsefede Kant'ın Kopernikçi devrimine gönderme olduğunu anlamaya mecbur kalırız. Dilthey'ın ve diğerlerinin modern düşünceye katkısı, Kant'ın düşüncesini bilimin ve matematiğin soyut ve evrensel alanının ötesinde kültürel deneyimin daha zengin daha karmaşık bir nüfus sahasına doğru genişletmek oldu. Kant'a olan borcunun farkında olan Dilthey, yorumlama üzerine olan teorik çalışmasını “Tarihsel Aklın Eleştirisi” adını verdiği daha geniş bir programın bir parçası olarak düşündü.

Popüler olarak perspektif denen şey, klasik ve doğru biçimiyle bu görsel mecazla hiçbir ilişkisi olmayan bir kurama atıfta bulunur. Bu noktada benim yorumum daha az mecazi ve felsefi olarak daha ciddi bir hâl almalıdır. Kant insanın öznelliğinde tecrübeyi oluşturan ve bu suretle bilimsel bilginin imkânını garantileyen evrensel bir yapı varsaydı. Dilthey ve diğerleri bu evrensel öznelliğin ötesinde bir kültürel öznelliğin var olduğunu farz ettiler. Bu kültürel öznellik kültürel tecrübeyi oluşturan başka kategoriler tarafından benzer şekilde oluşturulmuştur. Dithey ve onun okulundan olan kuramcılar şunun çok derinden farkındaydılar ki, bu kavrayışa göre, sözel anlam tamamen kültürel öznelliğe bağlıdır. Bilhassa şunu sormak daha öğretici olabilir: Bu kuramcılar Dilthey'ın kâbusunun şüpheci sonuçlarından kaçınmayı nasıl başarmışlardır?

Problem gerçekten ciddidir? Eğer bütün yorumlama, yorumcunun kafasındaki kültürel kategorilerle oluşturuluyorsa, farklı kültürel kategoriler tarafından oluşturulan anlamları nasıl anlayabiliriz? Dilthey'ın cevabı oldukça açıktı ve Kantçı geleneği destekleyici nitelikteydi. Kültürel olarak yabancı anlamları anlayabiliriz çünkü kültürel olarak yabancı kategorileri öğrenebiliriz. Herkes tarafından kabul edileceği gibi, Racine'i onun kastettiği anlamı oluşturan yabancı kategoriler yoluyla, yani onun kendi perspektifinden anlayabiliriz. Bununla birlikte onun kategorilerini uyarlayabiliriz; çünkü kültürel öznellik Kant'ın evrensel sistem kategorileriyle kıyaslanabilir bir epistemolojik uç nokta değildir. Kültürel öznellik doğuştan getirilmez fakat edinilir; insanın içinde var olan sonsuz sayıda kültürel olarak koşullanmış kategorik sistemi destekleyebilecek güçte bir potansiyelden türer. Herkesin kendini olduğundan başka biri gibi hayal etme veya kendi içinde başka bir insanı ya da başka bir kültürel ihtimali fark etme yeteneği vardır.

Fakat perspektif mecazı farklı bir sonucu zorunlu kılar. Her insan dünyayı farklı bir perspektiften gördüğü için, her birimiz diğerini kendince yanlış anlamak zorundadır. Görsel perspektif analojisinin bize öğrettiği ders budur. Yanlış yönlendirici olsa da içimizde olan bir şeydir ve kültürel kategorilerimizden biri olarak tanınması gerekir. Sonuç olarak bu görsel analojiyi fazla ciddiye alarak düştüğüm iki paradoksu belirtmeme izin verin. Aşağıdaki şüpheci argümana sürüklendim:

1. Her nesne farklı perspektiflerden farklı görünür.

2. Yorumcu bir metni yazarınkinden farklı bir perspektiften görür.

3. Dolayısıyla, yorumcunun kavradığı anlam çok az da olsa yazarınkinden farklı olmak zorundadır. 
Uzaysal görsel bir algının tasviri olarak bile bu sav deneysel açıdan doğru değildir. Mesela bir binayı bir caddeden gözlemlesem ve bir arkadaşım başka bir caddeden baksa, gördüğümüz şeydeki farklılık aslında perspektiflerimizin farklılığına dayandırılır. Sadece birkaç feet (fit) uzakta aynı caddede duruyor olsak bile, farklılıklar olacaktır. Farklılıklara rağmen aynı binayı algılamamız bir çelişkidir. Hiçbir perspektiften tamamen görülebilir olmayan bir nesneyi görürüz fakat buna rağmen hep birlikte onu algılar, bilir ve tanırız. Hayali bir genişlemeyle, tıpkı çift gözle bakıldığında elde edilen görüş etkilerinin tamamlanıp düzeltilmesi gibi, tek bir perspektiften elde ettiğimiz hayali görüşü tamamlar ve düzeltiriz. Binanın sadece bir yönünü görürsem, diğer yönlerinin de olduğunu, algıladığım nesnenin tüm bir nesne olduğunu, sadece benim gördüğüm yönden ibaret olmadığını bilirim. Ayrı bir yerde duran arkadaşım ve ben, aynı binayı gördüğümüz konusunda uzlaştığımızda haklıyızdır ve algımızın dış unsurlarının farklı olduğunu varsaymak da doğrudur. Burada işe karışan çelişki bilincin niyetselliğidir (intentionality), Husserl'in çalışmalarında olduğu gibi. Ve bu çelişki popüler perspektifçiliğin daha naif varsayımlarını yıkar. Perspektif etkileri her zaman anladı̆̆ımız şeyi bozup ikincil konumda bırakmaz. Perspektif mecazını ciddiye alan herkes görsel algının empirik gerçekleri tarafından ilk orijinal çıkarımını tersine çevirmeye zorlanır. Ve perspektiflerin çeşitliliğinin, idrak edilen anlamlarda bir çeşitlilik gerektirmediği sonucunu çıkarmaya mecbur kalır.

Dolayısıyla, şüpheci perspektifçi, Kantçı savın daha doğru öncüllerine doğru geri çekilse iyi eder. Bu en güçlü savunma hattıdır ve şüpheci perspektifçi layıkıyla şunu savunabilir; yerlerimizi değiştirip aynı fiziksel perspektiften baksak ta benim binam arkadaşımın binasından oldukça farklı olacaktır. Benim binam sadece fiziksel olarak verili bir nesne değil, benim özel kategorik sistemim tarafından oluşturulan bir nesnedir. Aynı nedenle, sözlü anlamın her yorumu onu çözümlemek için kullanılan kategoriler yoluyla oluşturulur. Fakat ona bakan herkes için, bu bina orda duran bir nesnedir. Sözlü anlam bu tür bir nesne değildir. Dilsiz bir metnin oluşturduğu bir anlam, sadece bilincimizde var olur. Ona mana yükleyen kategorilerden ayrık bir şekilde anlamın hiçbir varlığı yoktur. O halde bu perspektifçiliğin ikinci çelişkisidir. Nihayetinde üzerine kurulu olduğu Kantçı anlamanın bir uzantısı yoluyla, yorumcu perspektifçilik, kültürel kategorilerin yapıcı doğasını savunur. En derin anlamıyla, anlamın varlığını borçlu olduğu perspektif yoluyla var olduğunu ima eder. Ve bu da mecburen sözlü anlamın sadece bir perspektiften var olabileceği sonucuna götürür. Ve gene bu ikinci çelişkinin altında, perspektifçilik naif şüpheci çıkarımlarını bir kez daha yadsımak zorundadır. Artık farklı perspektiflerden anlamın farklı bir şekilde ortaya çıktığını varsayamaz. Anlamı farklı perspektiflerden görmenin kesinlikle imkânsızlığını kabul etmeye zorlanir.

Yabancı birinin perspektifinden görülemeyecek bir şeyi bozmak imkânsız olduğundan, yorumcunun yabancı perspektifinin anlamı bozduğunu savunmak en hafif şekliyle kaçamak bir cevap olur. Radikal perspektifler genellikle yeterince radikal değillerdir. Mesela H. G. Gadamer ufukların karşılaşmasından bahsettiğinde, bu orta yolcu perspektifin modern dünyaya taşıyormuş gibi yaptığı anlamı artık elinde tutmadığı çelişkisini gözden kaçırır. Tabii ki bir metnin sözcükleri yeni bir perspektiften yeniden dillendirilebilir ve yeni bir anlam formüllendirilebilir. Tabii ki bazı eleştirmenlerin 1srarla dile getirdiği gibi, okur kendi kendini şekillendiren bir yazar haline 
gelebilir. Fakat bir metin orijinal yazarının perspektifinden farklı bir perspektifle yorumlanamaz. Anlam ona varlığını veren perspektiften kavranır. Başka bir yöntem yorumlama değil, yazarlıktır.

Her yorumlama eylemi, bu nedenle, iki perspektif içerir, yazarınki ve yorumcununki. Normalde iki gözümüzle baktığımızda olduğu gibi perspektiflerin her ikisi de aynı anda akılda tutulur. Sıra dışı ya da hayali bir başarı olmaktan uzak bir biçimde, bu iki perspektifi birden anlama durumu insan ilişkilerinin temelidir ve dilbilimcilerin "çifte kişilik" dedikleri evrensel bir konuşma gerçeğidir. Konuştuğumuzda ya da bir konuşmayı yorumladığımızda, hiçbir zaman tek bir tinsel kategoriler matriksi içinde kapana kısılmayız, hiçbir zaman sadece dinleyici ya da sadece konuşmacı olmayız, aynı anda her ikisi birden oluruz. Bu yazının okurları, benim savımla empatik olarak hemfikir olmayanlar, şu an buradalar ve hem yorumu hem de eleştiriyi aynı anda icra ediyorlar ve iki perspektifi birden akıllarında tutuyorlar. Benim kastettiğim anlam vardır ve yalnızca benim perspektifimden mana kazanır, diğer taraftan bu anlama aynı anda getirilen eleştiriler farklı bir perspektifi ima eder. Sözlü iletişimde evrensel olan, bu çift perspektifin deneysel gerçekliği, yorumbilgisel (hermeneutik) göreceliğin temel öncüllerinden birini ve bununla birlikte bilişsel ateizmin şu zamanlar moda olan pek çok formunun doğruluğuna meydan okur. 


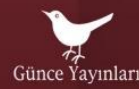

Prof. Dr. Önder Göçgün

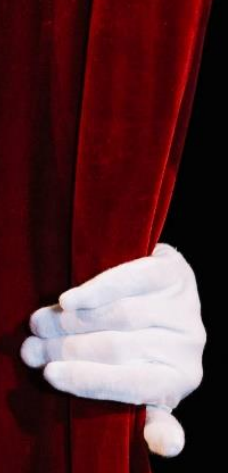

TIYYATRO DENEN HAYAT

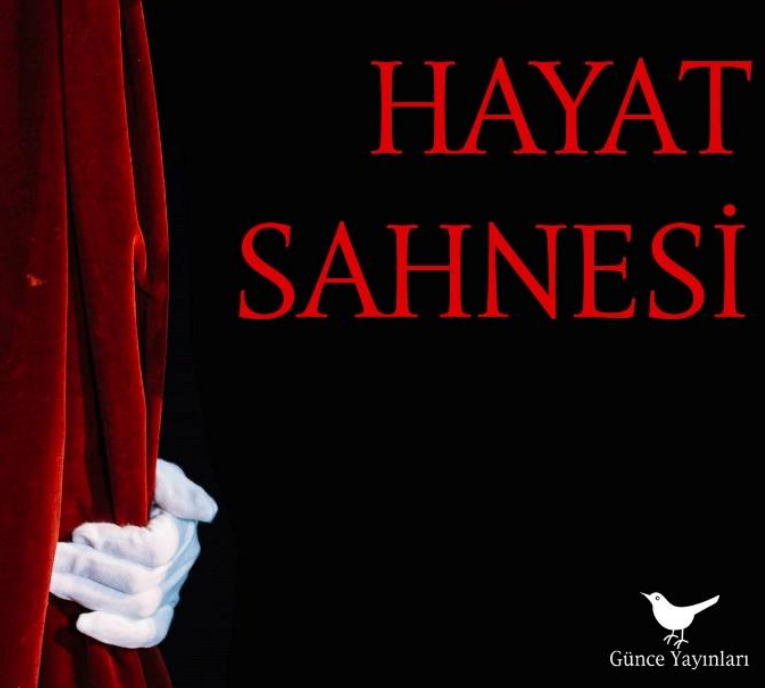

MUIIARREM DAYANC OKTAY YIVLI MACI'I BALIK MAIIMU'I BABACAN SLVIM SLERMEI
YASFMIN MUMCU BLDI் KOÇАKOĞLU NILÜLLLR ILLHAN MAKSUT YIĞITBAS SLL $\triangle M I I L \Lambda N$

\section{EDEBIYATINDA

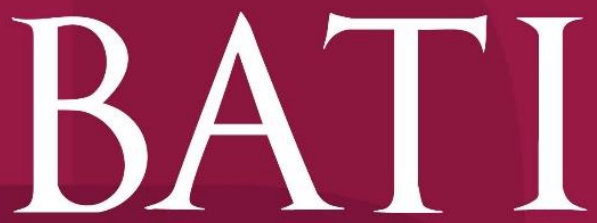 \\ EDEBIYATINDA
AKIMLAR \\ $\underset{\substack{\text { EDEBIYATINDA } \\ \text { AKIMLAR }}}{\mathrm{B} A T \mathrm{~T}}$}

editör

OKTAY YIVLI

HATICE FIRAT

YASEMIN MUMCU

OKTAY YIVLI

OĞUZHAN KARABURGU

BERNA AKYÜZ SIZGEN

NILÜFER ILHAN
ÜMMÜHAN TOPÇU

SEFA YÜCE

HANIFI ASLAN

METIN AKYÜZ

MEHMET SÜMER
YAKUP ÖZTÜRK
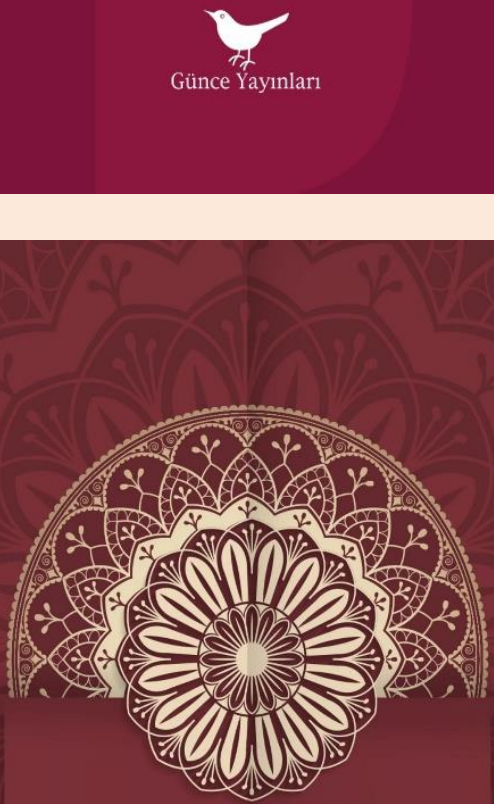

PROF. DR. ÖNDER GÖÇGÜN

$$
\begin{gathered}
\text { Türk } \\
\text { Tasavvuf } \\
\text { Siini }
\end{gathered}
$$

AÇIKLAMALI VE YORUMLU ÖRNEKLERLE 